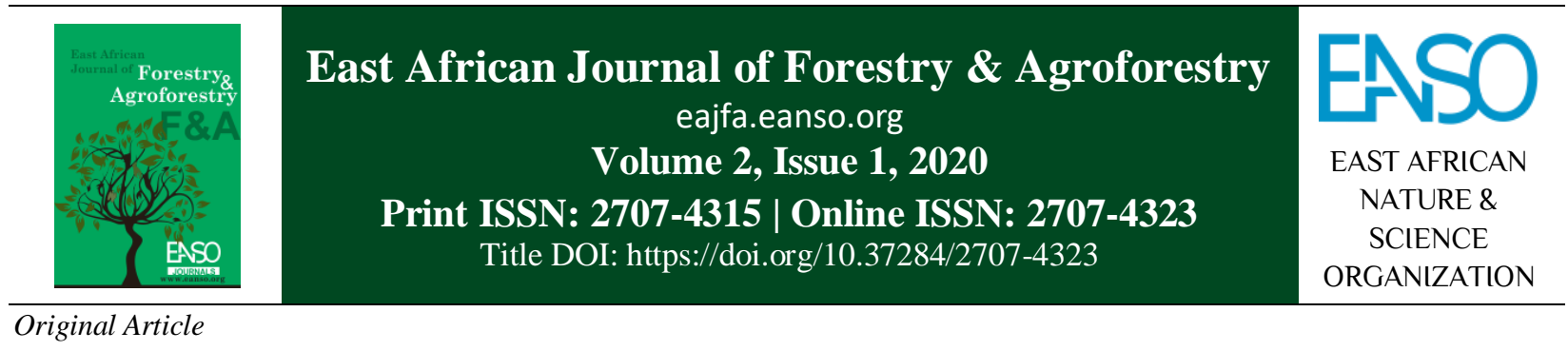

\title{
Faecal Glucocorticoids Metabolite Response in Giraffes (Giraffa camelopardalis tippelskirchi) in Relation to Protected Area Management Objectives in Tanzania
}

\author{
Dr. Wilfred N. Marealle ${ }^{*}$, Grethe Stavik Eggen ${ }^{2} \&$ Dr. Eivin Røskaft ${ }^{2}$ \\ ${ }^{1}$ Tanzania Wildlife Research Institute, Tanzania. \\ ${ }^{2}$ Department of Biology, Norwegian University of Science and Technology, NTNU, NO-7091 Trondheim, Norway. \\ * Author for correspondence email: marealle@bio.ntnu.no
}

Article DOI: https://doi.org/10.37284/eajfa.2.1.142

\section{Date Published: ABSTRACT}

26 Apr 2020 The increase in the human population and the demand for natural resources and recreational activities poses insurmountable threats to the welfare and survival

Keywords: of wildlife. Human disturbance negatively impacts wildlife populations. A prospective way of determining wildlife welfare is to assess stress. To manage

Giraffe, and conserve giraffes, it is vital to understand their stress factors and their

Stress, responses to stressors. This study used a non-invasive (faecal collection)

Faecal Glucocorticoids

Metabolite,

Serengeti,

Selous,

Protected Area, technique to evaluate the Faecal Glucocorticoid Metabolite (FGM) levels of giraffes depending on the protected area type, poaching risk, group size, age and sex. The study took place at the Serengeti National Park and Selous Game

Conservation. Reserve where a total of 63 faecal samples were randomly collected from 272 giraffe groups. A significant difference in the FGM levels between the sexes was found, as females had higher concentrations compared to males. In addition, a significant difference was found in relation to group size and age; however, protection type and poaching risk did not have any significant effect. Stressful conditions when prolonged can result in deteriorating animal welfare especially in calves and young animals thus their survival. However, the level of impaired FGMs and the amount of time required to produce damage are not known. In this regard, conservation strategies should seek to minimize the occurrence of stressful events in protected areas.

\section{APA CITATION}

Marealle, W., Eggen, G., \& Røskaft, E. (2020). Faecal Glucocorticoids Metabolite Response in Giraffes (Giraffa camelopardalis tippelskirchi) in Relation to Protected Area Management Objectives in Tanzania. East African Journal of Forestry and Agroforestry, 2(1), 47-58. https://doi.org/10.37284/eajfa.2.1.142 


\section{CHICAGO CITATION}

Marealle, Wilfred, Grethe Eggen, and Eivin Røskaft. 2020. "Faecal Glucocorticoids Metabolite Response in Giraffes (Giraffa Camelopardalis Tippelskirchi) in Relation to Protected Area Management Objectives in Tanzania". East African Journal of Forestry and Agroforestry 2 (1), 47-58. https://doi.org/10.37284/eajfa.2.1.142.

\section{HARVARD CITATION}

Marealle, W., Eggen, G. and Røskaft, E. (2020) "Faecal Glucocorticoids Metabolite Response in Giraffes (Giraffa camelopardalis tippelskirchi) in Relation to Protected Area Management Objectives in Tanzania", East African Journal of Forestry and Agroforestry, 2(1), pp. 47-58. doi: 10.37284/eajfa.2.1.142.

\section{IEEE CITATION}

W. Marealle, G. Eggen, and E. Røskaft, "Faecal Glucocorticoids Metabolite Response in Giraffes (Giraffa camelopardalis tippelskirchi) in Relation to Protected Area Management Objectives in Tanzania", EAJFA, vol. 2, no. 1, pp. 47-58, Apr. 2020.

\section{MLA CITATION}

Marealle, W., G. Eggen, and E. Røskaft. "Faecal Glucocorticoids Metabolite Response in Giraffes (Giraffa Camelopardalis Tippelskirchi) in Relation to Protected Area Management Objectives in Tanzania". East African Journal of Forestry and Agroforestry, Vol. 2, no. 1, Apr. 2020, pp. 47-58, doi:10.37284/eajfa.2.1.142.

\section{INTRODUCTION}

One in five vertebrate species is threatened with extinction where the threatened animals are categorized as vulnerable, endangered or critically endangered species (IUCN, 2016). The understanding hormonal activity provides an insight into animal and species biology and thus enhancing conservation initiatives (Kersey \& Dehnhard, 2014). The ever increasing human population coupled with increasing demands for bushmeat, human encroachment into wildlife areas, lack of alternative economic activities, political instability, poor governance and demand for wildlife body parts for traditional medicine has recently amplified threats towards wildlife (Challender et al., 2015; Holmern et al., 2004; Lee et al., 2014; Lindsay, 2012; Muller, 2011). There is little doubt that giraffe populations are under threat across Africa due to increasing human-wildlife conflict, loss of habitat and poaching (Marealle et al. 2010; Muller 2011).

Understanding the stress response of animals is essential to conservation because it will provide insights in the means to correct management problems before the outcomes become too severe as well as to ensure that the objectives of wildlife conservation are met (Wasser et al., 1997). Recently, many studies on stress physiology have been conducted on mammals (Hing et al., 2014). However, compared to other taxa, relatively little is known about the response of Masai giraffe (Giraffa camelopardalis tippelskirchi) to stressors and their conservation implications. Marealle et al. (2010) found that the sex ratio was female-skewed in potential stressful habitats or areas. In other similar studies, Lunde et al. (2016) found that human disturbances caused by traffic had a negative influence on the FGM levels on impala (Aepyceros melampus). Similarly, Tingvold et al. (2013) reported an increased level of stress hormones of African elephants (Loxodonta africana) living outside of protected areas (PAs) where human settlements were found compared to core protected areas.

Stress involves physiological and neurophysiological changes in an organism (Barja et al. 2007). Stress can be stimulatory, preparative or inhibitory (Creel et al., 2009; Hing et al., 2014). When an animal is stressed, hormones glucocorticoids (GCs) and catecholamines are released that may help in some positive situations such as mating, parturition, fleeing from predators and hunting for food. In contrast, stress may also have deleterious effects such as lowering the immune system, suppressing reproduction, affecting development and in some cases altering the behaviour of animals (Creel et al., 2002; Hing et al., 2014; Möstl \& Palme, 2002; Omsjoe et al., 2009; Palme 2012; Touma \& Palme, 2005). When stressed, an individual portrays a stress response to cope with the challenge (Touma \& Palme, 2005).

Stressors can be natural environmental factors or may result from human activities (Cabezas et al., 2007). Understanding the stress response to major threats, such as habitat loss and climate change is 
critical to conservation planning and also has economic implications (Hing et al., 2014; Millspaugh \& Washburn, 2004). Human disturbances are one of the major stressors to different species of wild animal populations (Creel et al., 2002; Moen et al., 1982) where direct chase or hunt by humans induces a stress response (Bateson \& Bradshaw, 1997). Giraffes ( $G$. camelopardalis Tippelskirchi) are exposed to a number of stressors such as but not limited to habitat loss, predation, climatic changes and anthropogenic disturbances (Cabezas et al., 2007). Assessing stress is fundamental for understanding and improving animal welfare, health, and reproduction (Touma \& Palme, 2005).

To manage and conserve giraffes, it is vital to understand their stress factors and their responses to stressors (Hing et al., 2014). This understanding can act as a proactive management tool enabling wildlife managers to optimize the trade-offs between resource utilization and the propagation of species at risk (Wasser et al., 1997). Therefore, we hypothesized that stress hormone levels (FGMs) are higher in the less protected areas that involve more human stressors. Furthermore, because poachers are constantly disturbing wildlife, the poaching risk influences the levels of FGMs; therefore, higher levels of FGMs were expected in areas with higher risks of poaching. It was also hypothesized that the FGM levels are influenced by group size with higher levels in smaller groups compared to larger ones and that there is no difference in the FGM levels between the age and sex of giraffes.

\section{RESEARCH METHODOLOGY}

\section{Study Area}

This study was conducted in the Serengeti National Park (SNP), 14,763 km² (Estes et al., 2012) and the northern part of the Selous Game Reserve (SGR) where giraffes are found in approximately $6 \%$ or $800 \mathrm{~km}^{2}$ (Brink et al. 2013) of the total $47,500 \mathrm{~km}^{2}$. In the SNP, any type of utilization is strictly forbidden. In the SGR, sustainable utilization is allowed and trophy hunting is practised under specified regulations (URT, 2002) except for giraffes. However, in both areas, illegal hunting has no exception. The density of human population is highest at the western and north-western borders of the Serengeti where poaching and other detrimental land-use practices have long been considered a serious threat in this ecosystem (Kideghesho et al., 2006; Marealle et al., 2010; Nyahongo, 2008; Setsaas et al., 2007). Likewise, a huge population of over 47,000 people resides around the buffer zones of the SGR, hence the pressure on the resources (Gillingham \& Lee 1999). The study areas were demarcated according to the illegal hunting risk areas as defined in (Marealle et al., 2010; Marealle et al., 2020) and the same considerations were taken into account while categorizing the risk areas in the SGR.

\section{Study Species}

Giraffes are the tallest savanna megaherbivore exploiting mainly tree leaves and twigs, which determine their distribution (Owen-Smith, 1988). Giraffes are ecologically adapted to go several days without water (Okello et al., 2015). They are sexually dimorphic (Marealle et al., 2010), nonterritorial and move in loose herds of which they form fluid groups (Leuthold \& Leuthold, 1978; Pratt \& Anderson, 1982). Giraffes have a major role in shaping savanna woodlands that impact the ecosystem structure and tourists are highly attracted to them (Bond \& Loffell, 2001).

Giraffes are exposed to a suite of potential humaninduced stress factor such as human population growth, illegal hunting, habitat loss and habitat fragmentation (GCF, 2014; Marealle et al., 2010; Muller, 2011) and naturally through increased predation pressure (Hayward \& Kerley, 2005; Owen-Smith, 2008; Sheepers \& Gilchrist, 1991). These factors contributed to the region-wide decline and extinction of native species (Corlett, 2007).

Although the giraffe range in the SGR falls within an area recently set aside for photographic tourism (Brink et al., 2013), the population is still subjected to the fear of the hunting disturbance. Similarly to many other PAs in the world, human population growth tends to be higher around protected areas (Caro, 1999; Mwamfupe, 1998; Packer et al., 2011). Surveys in the SNP showed a significant drop in giraffe densities especially in areas that previously supported large herds of giraffes. This was also reported in the SNP snare reports of which 
nearly $45 \%$ of victims were giraffes (Strauss et al., 2015). Vigilance studies evidently showed that humans and other ecological stressors such as predation posed a threat to giraffes (Marealle et al., 2010; Marealle et al., 2020; Periquet et al., 2010). When vigilant, an individual's head is raised up with a neck angle of $135^{\circ}$ or $180^{\circ}$ that lasts for at least 1 second without showing any other behaviour (Cameron \& Du Toit, 2005). Vigilance acts are used as an anti-predator strategy during courtship and for monitoring conspecifics (Cameron \& Du Toit, 2005). There was a positive relationship between vigilance and stress (Lima, 1998; Wiepkema \& Koolhaas, 1993) and therefore, elevated FGMs during vigilance (Arthur 1987).

\section{Faecal Glucocorticoid Metabolites (FGMs)}

Hormonal studies are currently being incorporated into wildlife research as a means to evaluate the health and physiology of individuals (Tarlow \& Blumstein, 2007). There are several methods for measuring stress in wildlife (Hing et al., 2014; Keay et al., 2006; Tingvold et al., 2013). However, this study focused on GCs as physiological measures of stress because they provide a mechanistic understanding of the physiological stress response compared to catecholamines, which are unstable with quite a short half-life (Hing et al., 2014; Palme et al., 2005). Faecal cortisol metabolites are a noninvasive method of measuring GCs that is particularly useful because samples can be easily obtained without disturbing the studied animals or interfering with the results (Millspaugh \& Washburn, 2004; Möstl \& Palme, 2002).

\section{Sample Collection}

After identifying a target group for faecal collection we stopped the vehicle and waited for 15-20 minutes and patiently observed the group while simultaneously recording the initial behaviour of individuals until members of the group defecated. Immediately after observing fresh dung, one person collected the pellets while another observer remained in the car and recorded the age and sex and counted individuals. A few pellets from the whole defecation that were not contaminated with dirt or urine were collected. After collection, we placed the sample(s) in a mobile portable freezer for temporary storage, which was later transferred to a stationed $20{ }^{\circ} \mathrm{C}$ freezer in the laboratory to reduce the possible metabolism by bacterial enzymes before analysis (Möstl \& Palme, 2002). A total of 63 faecal samples from 63 groups that were composed of 272 individuals were randomly collected taking into consideration age and sex over a 2-month period that is June - August 2015.

\section{Sample Processing}

The sample processing occurred at the Department of Biology, Norwegian University of Science and Technology (NTNU). Samples were thawed and pellets from a single individual were thoroughly crushed and mixed together to assure that the hormones were readily distributed. Then, measured $5 \mathrm{~g}$ (wet) and homogenised the sample was measured following (Lunde et al., 2016; Millspaugh \& Washburn, 2004; Palme, 2012; Palme et al., 2013; Tingvold et al., 2013). After homogenisation, $5 \mathrm{ml}$ of $80 \%$ ethanol was added to the sample and shaken for 30 minutes. This was followed by centrifuging the samples for 20 minutes at $3300 \mathrm{rpm}$. A $0.5-\mathrm{ml}$ aliquot of the supernatant was later transferred from each sample to a 0.5-ml Eppendorf cup. In total, 63 faecal samples from 63 individuals were collected. Each sample consisted of 4-5 pellets of varying shape and drop time; therefore, samples were treated differently when the 134 (1 control) faecal samples were processed. Samples were packed in a dry icebox and the hormone analysis was conducted in the laboratory of Dr. Rupert Palme, Institute of Physiology, Pathophysiology and Biophysics, University of Veterinary Medicine, Vienna, Austria. The enzyme immunoassay (EIA) used was the 11-oxoaetiocholanolone EIA as described in detail by Möstl \& Palme (2002) and it was found to be suitable for measuring FGMs in several ruminant species.

\section{Data analysis}

The data was analysed using SPSS 21.0 software for windows. A logistic linear regression analysis was used to test for interaction effect with the GC level used as a dependent variable with the following independent variables: protected area type, poaching risk, group size, age and sex. Descriptive statistics were used to determine the mean FGM levels on the same variables. For 
calculation purposes, the FGM levels were logtransformed $\left(\log _{10}\right)$ to normalize the data. The statistical significance was set at $\mathrm{P}<0.05$.

\section{RESULTS}

The FGM levels were recorded from a total of 272 groups. All of the hormone data were logtransformed before the statistical analyses and ranged from $4.01 \mathrm{ng} \mathrm{g}^{-1}$ to $7.22 \mathrm{ng} \mathrm{g}^{-1}$ faeces, with a $\log$ mean of $6.1 \mathrm{ng} \mathrm{g}^{-1}$ and a median of $6.2 \mathrm{ng} \mathrm{g}^{-1}$. A logistic regression analysis examining the log FGM

Table 1: A logistic regression analysis with $\log F G M$ in $n g$ g_l as the dependent variable and protection type, poaching risk, group size sex and age as independent variables

\begin{tabular}{llll}
\hline Faecal glucocorticoid metabolite (FGM) & & \\
\hline Independent variables & Rank & t & P= \\
\hline Sex & 1 & 4.672 & 0.0001 \\
Group size & 1 & -3.631 & 0.0001 \\
Type of protection & 2 & 0.983 & 0.327 \\
Age & 3 & 0.854 & 0.395 \\
Poaching risk & 4 & -0.809 & 0.420 \\
$\mathbf{R}^{2}$ & & 0.246 & 0.0001 \\
\hline Constant & & 19.147 & 0.0001 \\
\hline
\end{tabular}

level ( 0 to 1$)$ as the dependent variable was tested over the five explanatory independent variables of protected area type, poaching risk, group size, age and sex (Table 1). However, only two of the independent variables were highly significant contributors to the variation, altogether explaining $25 \%$ of this variation. The variable explaining most of the variation in FGMs was sex, and the second most important predictor was group size. Type of protection, age and poaching risk were insignificant.
The concentration levels of the mean FGM levels in different variables (sex, age, group size, protection type and poaching risk) are shown in Table 2 and Figures 1-3. The mean FGM level was found to be significantly higher in females compared to males (Figure 1). Furthermore, calves had higher FGM levels followed closely by young animals when compared to adults (Figure 2). The group size of 25 individuals had slightly higher levels of mean FGMs than the other groups (Figure 3). However, FGM level was not influenced by the type of protection.

Table 2: Mean log FGM test for different variables

\begin{tabular}{|c|c|c|c|c|}
\hline Variable & & Mean log FGM $\left(\right.$ ng g $\left.^{-1}\right)$ & SD $\left(\right.$ ng g $\left.^{-1}\right)$ & $\mathbf{N}$ \\
\hline Sex & Males & 5.8 & 0.7 & 54 \\
\hline & Females & 6.3 & 0.6 & 77 \\
\hline Age & Calves & 6.6 & 0.5 & 6 \\
\hline & Sub adult & 6.2 & 0.7 & 23 \\
\hline & Adults & 6.0 & 0.7 & 104 \\
\hline Group size & 1 & 6.1 & 0.5 & 16 \\
\hline & $2-5$ & 6.3 & 0.6 & 64 \\
\hline & $6-10$ & 6.0 & 0.8 & 37 \\
\hline & $11-30$ & 5.6 & 0.5 & 16 \\
\hline Protection type & Game Reserve-SGR & 6.0 & 0.8 & 57 \\
\hline & National Park-SNP & 6.1 & 0.6 & 76 \\
\hline Poaching risk & High & 6.2 & 0.6 & 75 \\
\hline & Low & 6.3 & 0.8 & 58 \\
\hline
\end{tabular}


East African Journal of Forestry and Agroforestry, Volume 2, Issue 1, 2020

Article DOI: https://doi.org/10.37284/eajfa.2.1.142

Figure 1: FGM concentrations (mean) between males and females

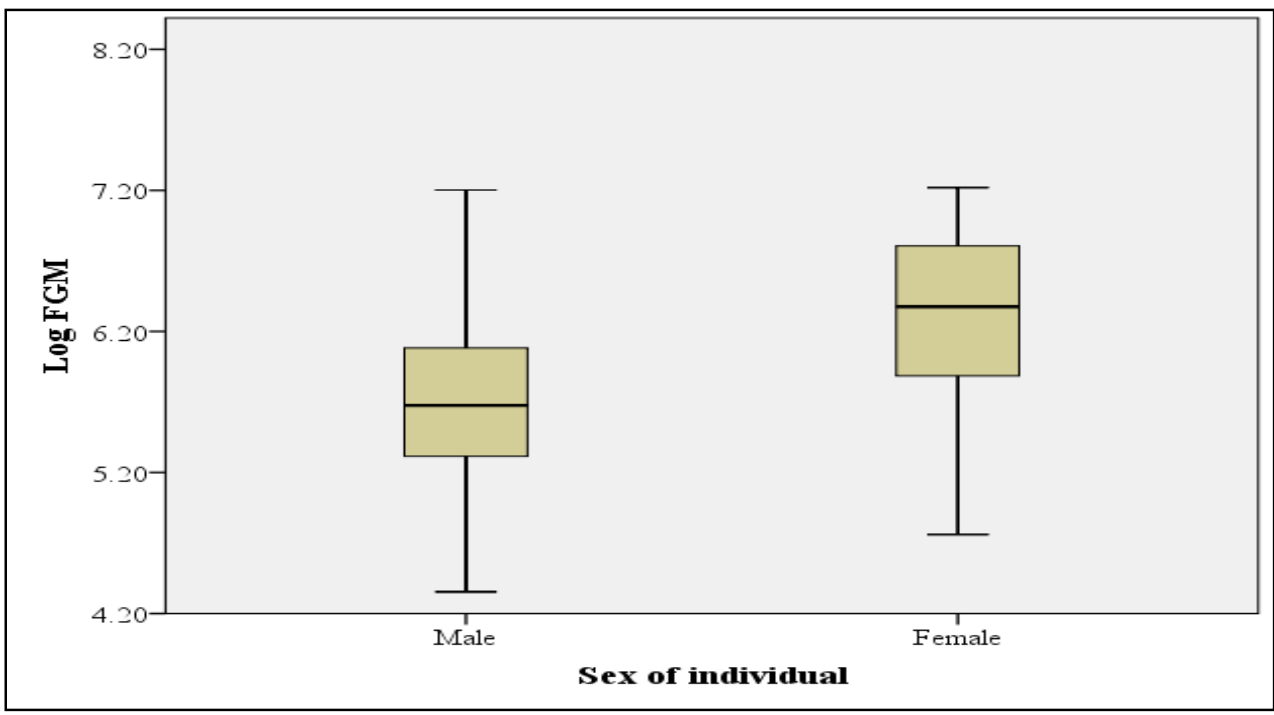

Figure 2: Mean levels of FGM in different age classes of observed giraffes.

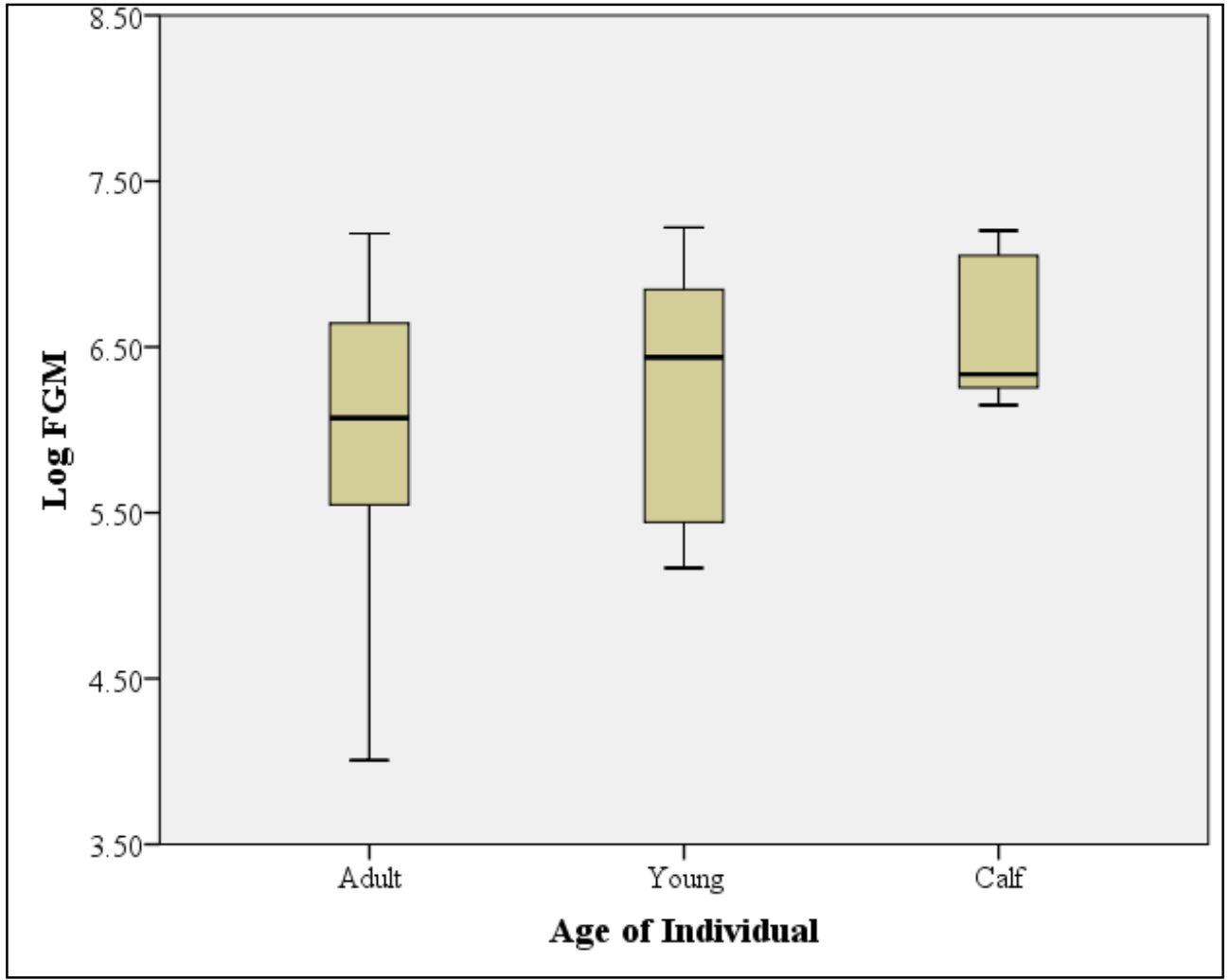


Figure 3: Distribution of mean FGM levels from giraffes divided into groups according to the number of individuals

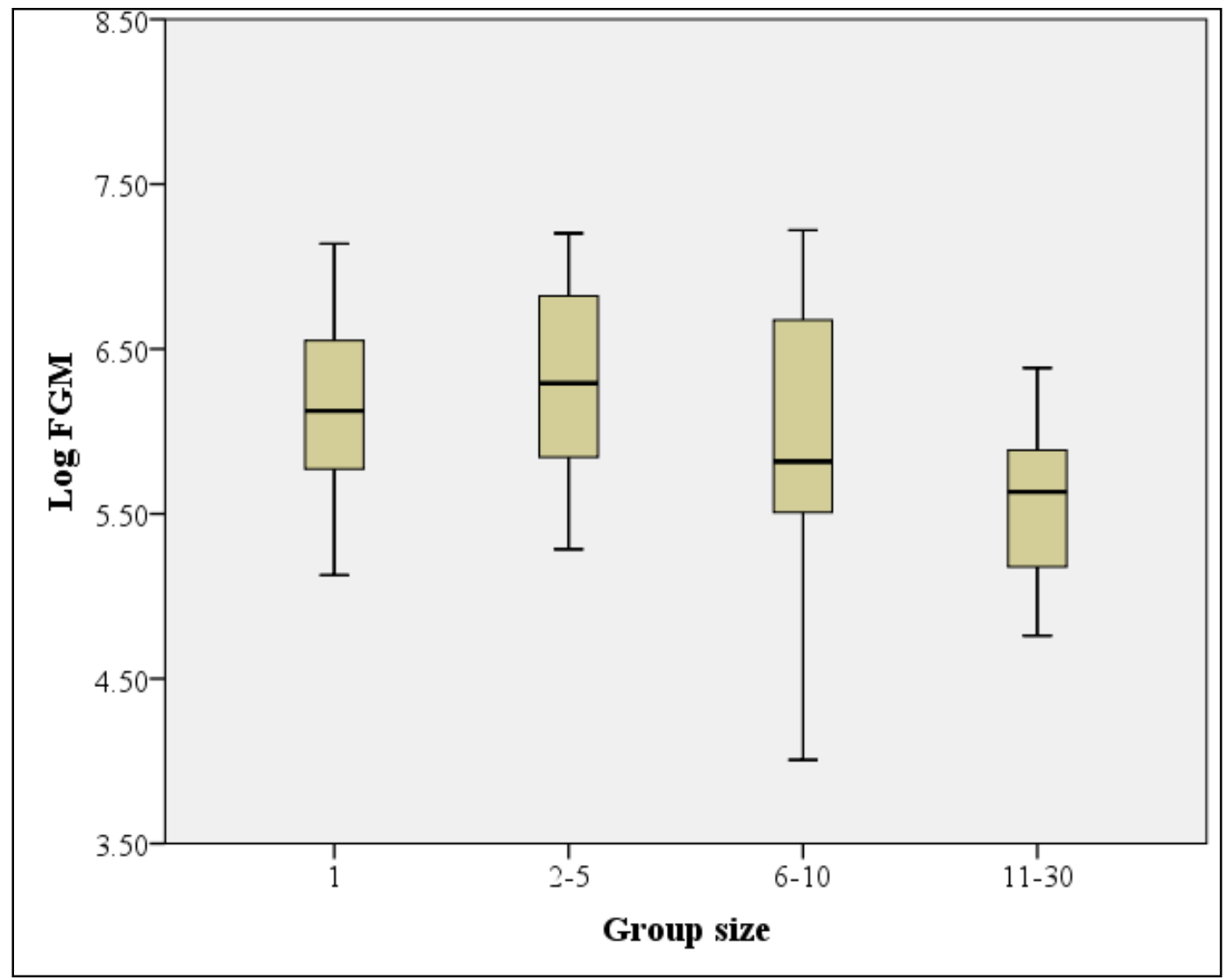

\section{DISCUSSION}

The results of the study did not indicate any significant differences in the levels of FGM concentrations of giraffes between SNP and SGR. However, in both areas, the mean stress levels were high. The study sites fall under different management objectives, specifically a National Park and a Game Reserve (Dudley, 2008; Phillips, 2002). Nevertheless, the part of the SGR where giraffes are found was converted from hunting blocks to a photographic tourism zone (Brink et al., 2013). The probable explanation for both areas having the same high levels of FGM was the presence of touristic activities (road networks) and incidences of poaching that took place within these areas. Similar effects were observed in other studies (Creel et al., 2002; Fowler, 1999; Lunde et al., 2016; Marealle et al., 2010; Müllner et al., 2004; Thiel et al., 2008; Walker et al., 2006) as well as in a recent behavioural study (Strauss et al., 2015). Tourist activities were spread almost equally in both high and low risk poaching areas. The FGM levels did show the same results in these two areas and had no significant difference and rather high FGM levels. These results were contrary to the hypothesis, as the anticipated differences were not observed.

Living in a group is very important for animal survival; however, it may also have some fitness consequences (Marealle et al., 2020; Pride, 2005; Shrader et al., 2006). In behavioural studies, evidence showed that stress in some cases increased costs such as agonistics while in other cases, costs were reduced such as vigilance with group size (Marealle et al., 2020; Pride, 2005). Our results conformed to our hypothesis, where significantly higher FGM levels were found in lower groups of $<10$ individuals and FGM levels decreased in extremely larger groups of $>11$ individuals. Animals tended to relax when they were in larger groups compared to smaller groups or singletons or they fled immediately when a threat was detected 
due to the many eyes effect (Burger \& Gochfeld, 1988; Ebensperger et al., 2006; Marealle et al., 2020; Setsaas et al., 2007) and with the relaxed state as a result of larger group sizes, the FGM levels also decreased.

Calves and young animals had higher FGM levels compared to adult individuals; however, most of the individuals in this category were found in larger herds of 2-30 individuals. Calves' FGM levels may be a direct result of ingesting maternal hormones during nursing and in young individuals, the FGM levels may be due to the effect of weaning (Hunt et al., 2006). It was also reported that tourism induced stress resulting in high FGM levels in younger animals that stayed longer in young individuals while adults can regulate FGM levels toward lower concentrations in a very short time (Hunt et al., 2006; Müllner et al., 2004; Walker et al., 2006). Higher levels of stress in young individuals may lead to higher mortality (Hatchwell, 1989; Müllner et al., 2004).

Different studies reported that gender could affect cortisol levels found in faeces (Keay et al., 2006; Touma \& Palme, 2005) and that the actions of stress varied with sex and were influenced by the predominance of particular sex steroids (Tilbrook et al., 2002). In our case, the level of FGMs was higher in females than males, which was contrary to our hypothesis. The results are supported by the study of Pride (2005) that found that females had higher FGM levels. The probable explanation for this result is that males were fluidly moving from one group to another and were able to maintain their FGM levels. In addition, male stress is group size dependant only during the mating season due to mate competition (Norscia et al., 2016) although giraffes are seasonal breeders. During this study, any mating behaviour was nor recorded and this might be the reason why the results did not show higher levels in males. The potential effect of stress in females was previously reported by Love et al. (2005) and Marealle et al (2010) where it influenced the female sex bias in calves in the SNP, meaning that stress was much more pronounced in females and its effect was evident during reproduction compared to males (James, 1996).

\section{CONCLUSION}

The non-invasive monitoring of stress hormones by using faecal samples has been largely applied to various species and has shown reliable results (Touma \& Palme, 2005). Tourism is of economic importance for Tanzania; however, mass tourism can jeopardise conservation goals (Zwijacz-Kozica et al., 2013). From our results, the variables that best explained the higher FGM levels in giraffes were group size, age and sex. However, like Lunde et al. (2016), the effect on fitness consequences associated with it was unknown, although a previous finding indicated that it affects the sexratio in calves (Marealle et al., 2010). The stressful conditions, when prolonged can result in deteriorating animal welfare and a declining population (Sapolsky, 2004). However, the level of impaired FGM and the amount of time required to produce damage are not known (Fowler, 1999). In this regard, conservation strategies should seek to minimize the occurrence of stressful events in protected areas, in particular, the human-induced stressors as their impacts are irreversible and stay longer especially in calves and young individuals.

\section{ACKNOWLEDGEMENTS}

We are grateful to the Norwegian government and the EU-AfricanBioServices (Grant Agreement 641918) project for funding this research and the study at the University of Science and Technology (NTNU). Furthermore, our sincere thanks are given to the Wildlife Division, Tanzania (WD), Tanzania Wildlife Research Institute (TAWIRI), Tanzania National Parks (TANAPA) and the Ngorongoro Conservation Area Authority (NCA) for granting us access to conduct this study. We would also like to extend our thanks to Tomas Holmern, Frode Fossøy, Mr. Elias Kalumbwa, Mercilian Iyulu and Mr. Valentine Mwamba for their help in the field and for fruitful discussions. 


\section{REFERENCES}

Arthur, A. Z. 1987. Stress as a state of anticipatory vigilance. Perceptual and motor skills 64:7585 .

Barja, I., G. Silván, S. Rosellini, A. Piñeiro, A. González-Gil, L. Camacho, and J. C. Illera. 2007. Stress physiological responses to tourist pressure in a wild population of the European pine marten. The Journal of Steroid Biochemistry and Molecular Biology, 104:136142.

Bateson, P., and E. L. Bradshaw. 1997. Physiological effects of hunting red deer (Cervus elaphus). Proceedings of the Royal Society B: Biological Sciences, 264:1707-1714.

Bond, W. J., and D. Loffell. 2001. Introduction of giraffe changes acacia distribution in a South African savanna. African Journal of Ecology, 39:286-294.

Brink, H., R. J. Smith, and K. Skinner. 2013. Methods for lion monitoring: a comparison from the Selous Game Reserve, Tanzania. African Journal of Ecology, 51:366-375.

Burger, J., \& Gochfeld, M. 1988. Effects of group size and sex on vigilance in ostriches (Struthio camelus): antipredator strategy or mate competition?. Ostrich, 59(1), 14-20.

Cabezas, S., J. Blas, T. A. Marchant, and S. Moreno. 2007. Physiological stress levels predict survival probabilities in wild rabbits. Hormones and Behaviour, 51:313-320.

Cameron, E. Z., and J. T. Du Toit. 2005. Social influences on vigilance behaviour in giraffes, Giraffa Camelopardalis. Animal Behaviour, 69:1337-1344.

Caro, T. M. 1999. Densities of mammals in partially protected areas: The Katavi ecosystem of western Tanzania. Journal of Applied Ecology, 36:205-217.

Challender, D. W. S., S. R. Harrop, and D. C. MacMillan. 2015. Towards informed and multi-faceted wildlife trade interventions. Global Ecology and Conservation, 3:129-148.
Corlett, R. T. 2007. The Impact of Hunting on the Mammalian Fauna of Tropical Asian Forests. Biotropica, 39:292-303.

Creel, S., J. E. Fox, A. Hardy, J. Sands, B. Garrott, and R. O. Peterson. 2002. Snowmobile Activity and Glucocorticoid Stress Responses in Wolves and Elk. Conservation Biology, 16:809-814.

Creel, S., J. A. Winnie, and D. Christianson. 2009. Glucocorticoid stress hormones and the effect of predation risk on elk reproduction. Proceedings of the National Academy of Sciences, 106:12388-12393.

Dudley, N. (eds). 2008. Guidelines for applying protected area management categories. Gland, Switzerland: International Union for Conservation of Nature (IUCN).

Ebensperger, L. A., M. A. J. Hurtado, and R. Ramos-Jiliberto. 2006. Vigilance and collective detection of predators in degus (Octodon degus). Ethology, 112:879-887.

Estes, A. B., T. Kuemmerle, H. Kushnir, V. C. Radeloff, and H. H. Shugart. 2012. Land-cover change and human population trends in the greater Serengeti ecosystem from 1984-2003. Biological Conservation, 147:255-263.

Fowler, G. S. 1999. Behavioural and hormonal responses of Magellanic penguins (Spheniscus magellanicus) to tourism and nest site visitation. Biological Conservation, 90:143149.

GCF. 2014. Conservation Status of Giraffe. Giraffe Conservation Foundation

Gillingham, S., and P. C. Lee. 1999. The impact of wildlife-related benefits on the conservation attitudes of local people around the Selous Game Reserve, Tanzania. Environmental Conservation, 26:218-228.

Hatchwell, B. 1989. The effects of disturbance on the growth of young Common Guillemots Uria aalge. Seabird, 12:35-39. 
Hayward, M. W., and G. I. H. Kerley. 2005. Prey preferences of the lion (Panthera leo). Journal of Zoology, 267:309-322.

Hing, S., Narayan, E., Thompson, R. C., \& Godfrey, S. (2014). A review of factors influencing the stress response in Australian marsupials. Conservation Physiology, 2(1).

Holmern, T., A. B. Johannesen, J. Mbaruka, S. Y. Mkama, J. Muya, and E. Røskaft. 2004. Human-wildlife conflicts and hunting in the western Serengeti, Tanzania. Page 26. NINA Project report 26. Trondheim, Norway: Norwegian Institute of Nature Research.

Hunt, K. E., R. M. Rolland, S. D. Kraus, and S. K. Wasser. 2006. Analysis of faecal glucocorticoids in the North Atlantic right whale (Eubalaena glacialis). General and Comparative Endocrinology, 148:260-272.

IUCN. 2016. Red List of Threatened Species. 20154. Gland, Switzerland: International Union for Conservation of Nature (IUCN).

James, W. H. 1996. Evidence that Mammalian Sex Ratios at Birth are Partially Controlled by Parental Hormone Levels at The Time of Conception. Journal of Theoretical Biology, 180:271-286.

Keay, J. M., J. Singh, M. C. Gaunt, and T. Kaur. 2006. Faecal glucocorticoids and their metabolites as indicators of stress in various mammalian species: a literature review. Journal of Zoo and Wildlife Medicine, 37:234244.

Kersey, D. C., and M. Dehnhard. 2014. The use of noninvasive and minimally invasive methods in endocrinology for threatened mammalian species conservation. General and comparative endocrinology, 203:296-306.

Kideghesho, J. R., Nyahongo, J. W., Hassan, S. N., Tarimo, T. C., \& Mbije, N. E. (2006). Factors and ecological impacts of wildlife habitat destruction in the Serengeti ecosystem in northern Tanzania. African Journal of Environmental Assessment and Management, 11, 17-32.
Lee, T. M., A. Sigouin, M. Pinedo-Vasquez, and R. Nasi 2014. The harvest of wildlife for bushmeat and traditional medicine in East, South and Southeast Asia: Current knowledge base, challenges, opportunities and areas for future research. CIFOR.

Leuthold, B. M., and W. Leuthold. 1978. Ecology of the giraffe in Tsavo East National Park, Kenya. African Journal of Ecology, 16:1-20.

Lima, S. L. 1998. Stress and decision-making under the risk of predation: recent developments from behavioural, reproductive, and ecological perspectives. Advances in the Study of Behaviour, 27:215-290.

Lindsay, P. 2012. Illegal hunting \& the bushmeat trade in Savanna Africa: Drivers. Impacts \& Solutions to Address the Problem, Panthera/WCS/ZSL. Traffic Report.

Love, O. P., Chin, E. H., Wynne-Edwards, K. E., \& Williams, T. D. (2005). Stress hormones: a link between maternal condition and sex-biased reproductive investment. The American Naturalist, 166(6), 751-766.

Lunde, E. T., Bech, C., Fyumagwa, R. D., Jackson, C. R., \& Røskaft, E. (2016). Assessing the effect of roads on impala (Aepyceros melampus) stress levels using faecal glucocorticoid metabolites. African journal of ecology, 54(4), 434-441.

Marealle, W. N., F. Fossøy, T. Holmern, B. G. Stokke, and E. Røskaft. 2010. Does illegal hunting skew Serengeti wildlife sex ratios? Wildlife Biology, 16:419-429.

Marealle, W., Holmern, T. and Røskaft, E. 2020. Factors Affecting Group Size and Vigilance Behaviour of Maasai Giraffe (Giraffa camelopardalis tippelskirchi) on the SerengetiNgorongoro Ecosystem, Tanzania. East African Journal of Environment and Natural Resources. 2, 1 (Apr. 2020), 14-23. DOI:https://doi.org/10.37284/eajenr.2.1.133.

Millspaugh, J. J., and B. E. Washburn. 2004. Use of faecal glucocorticoid metabolite measures in conservation biology research: considerations 
for application and interpretation. General and Comparative Endocrinology, 138:189-199.

Moen, A. N., Whittemore, S., \& Buxton, B. (1982). Effects of disturbance by snowmobiles on the heart rate of captive white-tailed deer [Odocoileus virginianus]. New York Fish and Game Journal.

Möstl, E., and R. Palme. 2002. Hormones as indicators of stress. Domestic Animal Endocrinology, 23:67-74.

Muller, Z. (2008). Quantifying giraffe poaching as population threat. The Rothschild's Giraffe Project. Retrieved from http://www.girafferesearch.com/\#/newsarticles/4542012258.

Müllner, A., K. Eduard Linsenmair, and M. Wikelski. 2004. Exposure to ecotourism reduces survival and affects stress response in hoatzin chicks (Opisthocomus hoazin). Biological Conservation, 118:549-558.

Mwamfupe, D. 1998. Demographic impacts on protected areas in Tanzania and options for action. Parks, 8:3-14.

Norscia, I., E. Palagi, A. Jolly, M. Huffman, and I. Tatterall 2016. The Missing Lemur Link: An Ancestral Step in the Evolution of Human Behaviour. Cambridge University Press.

Nyahongo, J. W. 2008. Flight initiation distances of five herbivores to approaches by vehicles in the Serengeti National Park, Tanzania. African Journal of Ecology, 46:227-229.

Okello, M. M., L. Kenana, H. Maliti, J. W. Kiringe, E. Kanga, F. Warinwa, S. Bakari, S. Ndambuki, H. Kija, N. Sitati, D. Kimutai, N. Gichohi, D. Muteti, P. Muruthi, and M. Mwita. 2015. Population status and trend of water dependent grazers (buffalo and waterbuck) in the KenyaTanzania Borderland. Natural Resources, 6(02), 91.

Omsjoe, E. H., A. Stien, J. Irvine, S. D. Albon, E. Dahl, S. I. Thoresen, E. Rustad, and E. Ropstad. 2009. Evaluating capture stress and its effects on reproductive success in Svalbard reindeer. Canadian Journal of Zoology, 87:73-85.
Owen-Smith, N. 2008. Changing vulnerability to predation related to season and sex in an African ungulate assemblage. Oikos, 117:602610.

Owen-Smith, R. N. 1988. Megaherbivores. The influence of very large body size on ecology. Cambridge, UK: Cambridge University Press.

Packer, C., H. Brink, B. Kissui, H. Maliti, H. Kushnir, and T. Caro. 2011. Effects of trophy hunting on lion and leopard populations in Tanzania. Conservation Biology, 25:142-153.

Palme, R. (2012). Monitoring stress hormone metabolites as a useful, non-invasive tool for welfare assessment in farm animals. Animal Welfare-The UFAW Journal, 21(3), 331.

Palme, R., S. Rettenbacher, C. Touma, S. M. ElBahr, and E. MÖStl. 2005. Stress Hormones in Mammals and Birds: Comparative Aspects Regarding Metabolism, Excretion, and Noninvasive Measurement in Fecal Samples. Annals of the New York Academy of Sciences, 1040:162-171.

Palme, R., C. Touma, N. Arias, M. Dominchin, and M. Lepschy. 2013. Steroid extraction: get the best out of faecal samples. Wien Tierarztl Monatsschr, 100:238-246.

Periquet, S., M. Valeix, A. J. Loveridge, H. Madzikanda, D. W. Macdonald, and H. Fritz. 2010. Individual vigilance of African herbivores while drinking: the role of immediate predation risk and context. Animal Behaviour, 79:665-671.

Phillips, A. 2002. Management Guidelines for IUCN Category V Protected Areas: Protected Landscapes/Seascapes. Gland, Switzerland, and Cambridge, UK: IUCN.

Pratt, D. M., and V. H. Anderson. 1982. Population, distribution, and behaviour of giraffe in the Arusha-National-Park, Tanzania. Journal of Natural History, 16:481-489.

Pride, R. E. 2005. Optimal group size and seasonal stress in ring-tailed lemurs (Lemur catta). Behavioural Ecology, 16:550-560. 
Sapolsky, R. M. 2004. Social Status and Health in Humans and Other Animals. Annual Review of Anthropology, 33:393-418.

Setsaas, T. H., T. Holmern, G. Mwakalebe, S. Stokke, and E. Røskaft. 2007. How does human exploitation affect impala populations in protected and partially protected areas? - A case study from the Serengeti Ecosystem, Tanzania. Biological Conservation, 136:563570.

Scheepers, J. L., \& Gilchrist, D. (1991). Leopard predation on giraffe calves in the Etosha National Park. Madoqua, 18(1), 49.

Shrader, A. M., Kerley, G. I., Kotler, B. P., \& Brown, J. S. (2006). Social information, social feeding, and competition in group-living goats (Capra hircus). Behavioral Ecology, 18(1), 103-107.

Strauss, M. K. L., M. Kilewo, D. Rentsch, and C. Packer. 2015. Food supply and poaching limit giraffe abundance in the Serengeti. Population Ecology, 57:505-516.

Tarlow, E. M., and D. T. Blumstein. 2007. Evaluating methods to quantify anthropogenic stressors on wild animals. Applied Animal Behaviour Science, 102:429-451.

Thiel, D., S. Jenni-Eiermann, V. Braunisch, R. Palme, and L. Jenni. 2008. Ski tourism affects habitat use and evokes a physiological stress response in capercaillie Tetrao urogallus: a new methodological approach. Journal of applied ecology, 45:845-853.

Tilbrook, A., A. Turner, and I. Clarke. 2002. Stress and reproduction: central mechanisms and sex differences in non-rodent species. Stress, 5:83100.

Tingvold, H. G., R. Fyumagwa, C. Bech, L. F. Baardsen, H. Rosenlund, and E. Røskaft. 2013. Determining adrenocortical activity as a measure of stress in African elephants (Loxodonta africana) in relation to human activities in the Serengeti ecosystem. African Journal of Ecology, 51:580-589.
Touma, C., and R. Palme. 2005. Measuring Fecal Glucocorticoid Metabolites in Mammals and Birds: The Importance of Validation. Annals of the New York Academy of Sciences, 1046:5474.

URT. 2002. The Wildlife Conservation Act, 2002. Ministry of Natural Resources and Tourism. CAP 283. Retrieved from http://www.mnrt.go.tz/uploads/tanzania_wildli fe_conservation_act_2002.pdf.

Walker, B. G., P. Dee Boersma, and J. C. Wingfield. 2006. Habituation of Adult Magellanic Penguins to Human Visitation as Expressed through Behavior and Corticosterone Secretion. Conservation Biology, 20:146-154.

Wasser, S. K., K. Bevis, G. King, and E. Hanson. 1997. Noninvasive Physiological Measures of Disturbance in the Northern Spotted Owl. Conservation Biology, 11:1019-1022.

Wiepkema, P. R., and J. M. Koolhaas. 1993. Stress and Animal Welfare. Animal Welfare, 2:195218.

Zwijacz-Kozica, T., N. Selva, I. Barja, G. Silván, L. Martínez-Fernández, J. C. Illera, and M. Jodłowski. 2013. The concentration of faecal cortisol metabolites in chamois in relation to tourist pressure in Tatra National Park (South Poland). Acta theriologica, 58:215-222. 